\title{
The multi-functional role of insulin-like growth factor binding proteins in bone
}

\author{
Kristen E. Govoni \\ Musculoskeletal Disease Center, Jerry L. Pettis VA Medical Center, 11201 Benton Street, Loma \\ Linda, CA 92357, USA. Department of Medicine, Loma Linda University, Loma Linda, California, \\ USA
}

\section{David J. Baylink}

Musculoskeletal Disease Center, Jerry L. Pettis VA Medical Center, 11201 Benton Street, Loma Linda, CA 92357, USA. Department of Biochemistry, Loma Linda University, Loma Linda, California, USA

\section{Subburaman Mohan \\ Musculoskeletal Disease Center, Jerry L. Pettis VA Medical Center, 11201 Benton Street, Loma Linda, CA 92357, USA, Tel.: +1-909-8257084 ext. 2932, Fax: +1-909-7961680. Departments of Medicine, Biochemistry and Physiology, Loma Linda University, Loma Linda, California, USA}

Subburaman Mohan: Subburaman.Mohan@med.va.gov

\section{Abstract}

The insulin-like growth factor (IGF) system is an important regulator of bone formation. The IGFs (IGF-I and IGF-II) are the most abundant growth factors produced by bone, and are regulated by their six high affinity binding proteins (IGFBPs). The IGFBPs are produced by osteoblasts and are responsible for transporting the IGFs and extending their half-lives. In general, IGFBP-1, -2, -4, and -6 inhibit and IGFBP- 3 and -5 stimulate osteoblast function. IGFBP- 4 and -5 are the most abundant IGFBPs produced by osteoblasts, and therefore they are the primary focus of this review. IGFBP-5 is an important stimulator of bone formation and may also function independently of IGFs. IGFBP-4 inhibits osteoblast function by sequestering IGF and preventing it from binding to its receptor. This review focuses on the specific IGF-dependent and IGF-independent roles of the IGFBPs in bone formation, as well as their potential mechanisms of action. In addition, discussion of the regulation of the IGFBPs by post-translational modification (i.e., proteolysis) has been included. Studies on the regulation of production and actions of IGFBPs suggest that the IGFBP system in bone is pleiotropic and capable of serving multiple effector inputs from systemic and local sources.

\section{Keywords}

Insulin-like growth factor binding proteins; Insulin-like growth factors; Bone; Osteoblasts; Growth

\section{Introduction}

The growth hormone (GH)/insulin-like growth factor (IGF-I and IGF-II) axis is important in the regulation of growth and development. Insulin-like growth factors-I and -II are the most 
abundant growth factors produced by osteoblasts, and exert important effects on the proliferation, differentiation, and apoptosis of osteoblasts. Accordingly, mice lacking functional IGF-I exhibit severe deficiency in bone formation and a $60 \%$ deficit in peak bone mineral density (BMD) [1]. Furthermore, patients with disruption of the IGF-I gene exhibit a peak BMD of five to six standard deviations lower than corresponding age-matched normal subjects $[2,3,4]$. Studies on the mechanisms by which the actions of IGFs are regulated in bone and other tissues have revealed that the IGF system is pleiotropic, consisting of multiple components, which include GH, IGF-I, IGF-II, the type I and type II IGF receptors, six high affinity IGF binding proteins (IGF-BPs), IGFBP proteases, and inhibition and activation of IGFBP proteases [5].

In recent years, one component of the IGF system, the IGFBPs, have received considerable attention as regulators of IGF actions. Although it is well accepted that, in general, the IGFBPs are responsible for transporting IGFs in the circulation and extending their halflives, the exact physiological functions and mechanisms by which the IGFBPs act are still not completely known. The IGFBPs have been reported to have stimulatory or inhibitory actions on the IGFs in bone, and recent experiments have provided evidence that some of IGFBPs function independently of IGF to increase parameters of bone formation. Studies on the molecular mechanisms by which IGFBPs mediate their IGF-dependent and IGFindependent effects have revealed evidence for complex mechanisms, involving both transcriptional and post-transcriptional (i.e., IGFBP proteases) mechanisms that vary depending on the IGFBP and cell type studied. In addition, the finding that IGFBPs are produced in greater abundance than IGFs by bone cells is consistent with the concept that IGFBPs are important regulators of osteoblasts. Therefore, this review will focus on the role of IGFBPs in the regulation of IGF action in bone formation, with an emphasis on the roles of IGFBP-4 and -5, the two most abundant IGFBPs in bone.

\section{Basic studies to clarify clinical issues relevant to the IGF system}

Bone formation is an important process in all species. In humans, when there is an uncoupling of this process and bone resorption exceeds bone formation, osteoporosis or bone fragility may occur. Osteoporosis, a disease characterized by a low BMD, is a major health concern in humans. Therefore, it is important that we have a full understanding of the factors that regulate bone formation and resorption, as well as how these factors themselves are regulated. Many experiments have examined factors, such as parathyroid hormone (PTH), bone morphogenic protein (BMP), vitamin D, GH, and IGFs, which are associated with attaining peak bone density during periods of growth and development in humans and animals. The IGF system plays a critical role in the regulation of bone formation, with IGF-I positively correlated with BMD. Following birth in mice, there is a transition between IGFII and IGF-I, such that IGF-I is the predominant IGF during puberty, a rapid growth period when $40 \%-50 \%$ of bone accretion occurs. For example, compared with IGF-I and GH knockout mice, there is less of a decrease in body weight, bone mineral content, and BMD in IGF-II knockout mice [1]. Therefore, the GH/IGF system is critical in mediating bone accretion during puberty, with IGF-I being the predominant IGF.

In general, GH stimulates the release of the IGFs from the liver, and the IGFs have endocrine effects. However, many tissues, such as bone, muscle, and adipose, secrete IGFs for paracrine and autocrine effects. Until recently, it was believed that liver IGF-I was necessary for normal pre- and post-natal growth, since mice with a null mutation for IGF-I had decreased growth and bone development, with many dying after birth [6,7]. However, this was questioned when Yakar et al. [8,9] used the cre-lox approach to knockout IGF-I in mouse liver. In the liver of IGF-I knockout mice, there was a 75\% reduction in circulating IGF-I; however, these mice underwent normal growth and development [8]. At this point, it 
was speculated that autocrine and/or paracrine IGF-I might be able to support normal postnatal growth.

Since the IGFs are often found in a tertiary complex with acid labile subunits (ALS) and an IGFBP in the circulation, it was hypothesized that deletion of ALS would also affect normal growth. In the ALS knockout mice, there was a $65 \%$ reduction in circulating IGF-I and a $10 \%$ reduction in body weight compared with control mice [9]. When IGF-I and ALS were both knocked out, there was a drastic reduction in circulating IGF-I to $10 \%-15 \%$ of controls, as well as a decrease in bone formation and overall growth [9]. These data in IGFI/ALS knockout mice, which had the greatest decrease in circulating IGF-I, indicate that a threshold level of IGF-I in the circulation may be required for normal growth. These experiments support the importance of endocrine IGF-I in regulating growth and development; however, further work is needed to determine the relative contribution of endocrine versus autocrine/paracrine IGF-I in bone regulation.

The IGFs (IGF-I and -II) are the most abundant growth factors stored in bone and produced by osteoblasts [10]. The IGFs are also produced by osteoclasts and act in an autocrine/ paracrine manner to regulate bone resporption and/or formation; however, fewer experiments have examined the role of IGF-I in bone resorption [5]. During periods of growth, such as puberty or following GH treatment, serum concentrations of IGF-I are positively correlated with bone formation markers, osteocalcin, and alkaline phosphatase (ALP) $[11,12,13]$. The IGFs increase bone formation by regulating proliferation, differentiation, and apoptosis of osteoblasts $[5,11,14]$. In bone, the IGFs primarily act by binding to the type I receptor. The IGFBPs regulate the IGFs by preventing their binding to the receptor and/or by regulating the amount of IGFs in the circulation that are available to local tissues. Since IGFs cannot act when bound to IGFBPs, IGFBPs must also be regulated. The IGFBPs are regulated by specific proteases that cleave IGFBPs, thus reducing their IGF binding affinity dramatically. The IGF is then released and is able to bind to its receptor. Thus, the pleiotropic nature of the IGF system allows an organism to accurately regulate IGF actions depending on the systemic and local needs.

\section{General structural features of IGFBPs}

Across all IGFBPs, the structures are highly conserved. IGFBPs have three main domains and several sub-domains, all of which are important for their specific functions. The central domain has almost no structural conservation between the six IGFBPs and accounts for the variation in the actions of IGFBPs [15]. The IGFBPs each have a conserved amino-terminal domain with six disul-fide bonds, except IGFBP-6, which has five disulfide bonds, and a conserved cysteine-rich carboxyl-terminal domain with three disulfide bonds, most of which are included in IGF-binding domains [15]. There is variation between IGFBPs in terms of which terminal is involved in IGF binding and this may explain the different affinities for IGF-I and -II observed between the IGFBPs. For example, we determined that IGFBP-4 contains a single binding site for IGF-I and IGF-II and binds them with equal affinity [16]. This site is located in the amino-terminal, since amino-terminal fragments of IGFBP-4 retained IGF binding activity. Although the IGFBP-4 fragments did not contain independent IGF binding sites in the carboxyl-terminal, both the amino- and carboxyl-terminals are required for optimal IGF-binding [16]. In contrast, IGFBP-2, -5, and -6 have a greater affinity for IGF-II than IGF-I [17]. Therefore, these IGFBPs may have separate binding sites for IGF-I and -II [16].

Although IGFBPs are highly conserved, the differences in structure contribute to their specific activity, their association with IGFs, and their roles in different experimental conditions. The IGFBPs can be associated with cell surfaces and are regulated post- 
translationally by phosphorylation and glycosylation [15,18]. IGFBP- $1,-3$, and -5 are secreted as phosphoproteins; however, phos-phorylation only appears to affect IGF binding affinity of IGFBP-1 [18]. For example, in humans, phosphorylated IGFBP-1 has a six-fold greater affinity for IGF-I than non-phosphorylated IGFBP-1 and this keeps IGFBP-1 from binding to the cell surface $[15,18]$. IGFBP-3 is primarily found in the glycosylated from and is $N$-gly-cosylated, whereas IGFBP-1, -5 , and -6 are $O$-glycosy-lated [15]. Aside from potentially altering the cell association of IGFBPs, the functional implications of phosphorylation and glycosylation of IGFBPs are not completely understood. For a morecomplete review of the structural features of IGFBPs and their interactions with the IGFs, the authors direct the reader to the following reviews $[15,18]$.

\section{General functional features of IGFBPs}

The important actions of the IGFs are regulated by six high-affinity IGFBPs, which bind IGFs with an affinity at least equal to or greater than the binding of IGFs to the IGF receptors [19]. In general, IGFBPs act in the serum to regulate the endocrine as well as local actions of the IGFs. The IGFBPs prolong the half-life, prevent insulin-like activity, and control the bioavailability of the IGFs [20]. About $75 \%$ of the IGFs in serum circulate bound to a 150 -to $200-\mathrm{kDa}$ complex, which consists of a 7.5-kDa IGF-I/IGF-II, a 38- to 43-kDa IGFBP-3, and an 80- to 90-kDa ALS $[10,17,18,19]$. This large complex acts as a reservoir and cannot cross the endothelial barrier [17]. To a lesser degree, IGFBP-5 may also be found in a tertiary complex with IGF and ALS [15]. In adult humans, about $90 \%$ of IGFBP-3 and $55 \%$ of IGFBP-5 are found in this large complex [18]. About $20 \%-25 \%$ of the IGFs are found in a smaller $40-$ to $50-\mathrm{kDa}$ binary complex with the other IGFBPs. The smaller complex is able to cross the vascular endothelium, at which point the IGFBPs can be proteolyzed by specific proteases, allowing IGF to bind to its receptor.

In addition to regulating the activity of IGFs in the circulation, IGFBPs have also been shown to function as local regulators of IGF action in bone and other tissues. The role of IGFBPs can vary considerably at the local level depending on the experimental conditions as well as how they are regulated by factors such as phosphorylation, proteolysis, and IGFBPcell surface association [17]. The primary roles of IGFBPs are dependent on the IGFs and they can either inhibit or stimulate IGF actions; however, some IGFBPs exhibit both actions. Specifically, IGFBP-1, $-2,-4$, and -6 primarily inhibit the IGFs by binding to them and preventing them from binding to their receptors $[19,21,22]$. IGFBP- 3 and -5 stimulate the actions of the IGFs because they bind IGF in a tertiary complex and make it available in the circulation. Specifically, IGFBP-5 associates with proteins on the cell surface and increases local concentrations of IGFs in the vicinity of the IGF receptors [23].

The IGFBPs also have IGF-independent roles in cell migration, cell growth, and apoptosis [20]. In Chinese hamster ovary cells transfected with IGFBP-1, cell migration increased in the absence of IGF-I [24]. Recently it has been determined that these IGF-independent actions of IGFBP- 1 are a consequence of binding to an $\alpha 5 \beta 1$ integrin receptor [25]. In a previous review, we discussed many studies that support the role of IGFBP-3 in cell growth and apoptosis [20]. These actions were independent of IGF signaling. We also reported, through indirect evidence, that IGFBP-5 independently increases differentiation of MG63, human osteosarcoma cells that do not produce IGF-I or II [26]. Additional direct evidence that IGFBP-5 promotes cell growth in IGF-I-deficient cells further supports the role of IGFBP-5 in IGF-independent cell growth [27]. The IGFBPs can act independently of the IGFs by binding to putative cell surface receptors as well as through nuclear localization and interaction with transcriptional modulators [20]. Overall, the IGFBPs have multifunctional roles in bone as well as other tissues, and the variation in their roles is related to the cell type, experimental condition, and how they are regulated (i.e., proteolysis). 


\section{Functions of IGFBPs in bone}

This review will focus on the role of IGFBPs in bone. For further information about IGFBPs in other tissues, please refer to one of our previous reviews [17]. Osteoblast cells produce all six IGFBPs; however, the amount of each binding protein varies depending on the site of expression and species [20]. For example, IGFBP-3, -4 , and -5 are most actively produced in vertebral cells, mandibular cells, and calvarial cells, respectively [5]. As previously stated, IGFBPs can be found in tertiary or binary complexes, which determine its role in osteoblast function (Fig. 1). The expression of the individual IGFBPs also depends on the type and stage of osteoblast cell differentiation [5]. As in other tissues, IGFBPs in bone can inhibit or potentiate the actions of IGFs on osteoblasts and osteoclasts [17,19,23,28,29]. In general IGFBP-1, -2, -4, and -6 inhibit IGF action and IGFBP- 3 and -5 stimulate IGF action in bone. This is supported by in vitro data that demonstrate that IGFBPs that inhibit IGFs are associated with decreased osteoblast proliferation, whereas the IGFBPs that stimulate IGFs are associated with increased osteoblast proliferation and bone formation [5]. These data parallel in vivo data that demonstrate that potentiating IGFBPs increase with increased growth and bone formation, whereas inhibitory IGFBPs decrease with decreased growth and decreased bone formation [5].

We recently reported indirect evidence that circulating components of the IGF system contribute to an impairment of bone formation, a condition associated with bone loss [30]. Specifically, in patients with osteoporosis, an imbalance in IGFBPs occurs such that there is an increase in inhibitory proteins (IGFBP-1, 2-, 4, and -6) and a decrease in stimulatory proteins (IGF-I, IGFBP-3, and -5), which is further aggravated in patients with fractures [30]. Although the binding proteins have general stimulatory or inhibitory functions within the body as well as bone, the specific functions of each IGFBP are dependent on the cell type and conditions of the experiment. Therefore, this review will go into further detail about the role of IGFBPs in bone with special emphasis on IGFBP-4 and -5 .

\section{Role of IGFBP-5 in bone}

IGFBP-5 is the most abundant IGFBP stored in bone [14] and plays an important role in the regulation of bone formation. In 1991, we discovered that IGFBP-5 was largely responsible for regulating IGF-II storage in bone [31], although the mechanism by which IGF-II could bind to bone was unknown. Shortly after, we determined that IGFBP-5 could bind to hydroxyapatite, which provided a link between IGF-II and bone [31]. In addition, IGFBP-5 can bind to extracellular matrix proteins, thus providing another mechanism for IGFs to adhere to the bone cell surface $[23,31,32]$. Since then, numerous in vivo and in vitro experiments have confirmed the importance of IGFBP-5 in the regulation of bone formation $[5,14,26,27,33,34]$. Based on recent in vitro and in vivo data, we can speculate on the mechanisms by which IGFBP-5 may potentiate IGF action (Table 1); however, further work is still required to confirm the extent to which these mechanisms are involved in mediating IGF-dependent actions of IGFBP-5.

Similar to the IGFs, IGFBP-5 is positively correlated with growth and bone formation, such that it increases with growth or GH treatment and decreases with age and decreased bone formation $[5,32,35]$. Although some of the other IGFBPs may have both inhibitory and stimulating effects on the IGFs, IGFBP-5 is the only IGFBP that consistently stimulates proliferation of osteoblast cells in vitro [27]. There are several reports that IGFBP-5 stimulates bone formation parameters in vitro and in vivo $[26,35,36]$. In addition, in several different cell lines, IGFBP-5 has been reported to stimulate basal and IGF-induced cell proliferation [5,27,31,35]. Similarly, IGFBP-5 administration in vivo stimulates bone formation parameters (osteocalcin, ALP), but not serum concentrations of IGF-I [26,35]. This indicates that, in addition to possessing IGF-dependent actions, IGFBP-5 may also 
function independently of IGF-I. IGFBP-5 has also been reported to stimulate osteoclast bone resorption by augmenting IGF-I; however, this only occurred in the presence of osteoblasts; therefore, the action of IGFBP-5 on osteoclasts may be indirect [29].

In contrast to the positive effects of IGFBP-5 on bone formation parameters, IGFBP-5 overexpression using the osteocalcin promoter revealed significant reductions in trabecular bone volume at 5 weeks of age [34]. It is possible that the osteoblast response to IGFBP-5 may vary with dose or may be different with continuous versus intermittent IGFBP-5 exposure, as is the case with PTH [37]. The observed inhibitory effects of transgenic overexpression of IGFBP-5 are similar to our unexpected findings that systemic administration of pharmacological doses of inhibitory IGFBP-4 increased bone formation parameters. In any case, based on the findings that serum levels of IGFBP-5 correlate positively with BMD in several clinical studies, and based on a number of in vitro and in vivo studies on the effects of IGFBP-5 on bone formation parameters, we predict IGFBP-5 to function as a stimulatory binding protein in bone.

In terms of the mechanisms by which IGFBP-5 treatment increases bone formation, we have reported in vivo and in vitro data that demonstrate IGFBP-5 functions as a growth factor independent of IGF (Fig. 2) [27]. In IGF-I knockout and wild type mice and mouse osteoblasts from IGF-I knockout and wild type mice, IGFBP-5 but not IGF-I administration increased proliferation and ALP activity [27]. IGFBP-5 binds to a putative receptor on the cell surface to stimulate serine/threonine kinase activity and protein phosphorylation $[5,33]$. Based on these data, it has been speculated that IGFBP-5 acts independently of IGF by binding to a putative receptor [33]. However, the identity of the IGFBP-5 receptor remains unknown at present.

IGFBP-5 may also regulate bone formation through regulation of gene transcription [14]. In this regard, IGFBP-5 contains a nuclear localization sequence that facilitates its transport to the nucleus [38,39]. In addition, we have new evidence that IGFBP-5 interacts with four and a half lim protein 2 (FHL2), which was supported by the localization of both FHL2 and IGFBP-5 in the nucleus [14]. Using a yeast two-hybrid system, we identified several FHL2 cDNAs in which the C-terminal regions contain at least two LIM domains that are sufficient for IGFBP-5 and FHL2 to interact [14]. FHL2 interaction is specific for IGFBP-5 among the IGFBPs expressed in normal human osteoblasts, and it may be regulated by p53 [14]. Because IGFBP-5, but not FHL2, contains a nuclear localization signal (NLS), we hypothesize that this interaction facilitates transport of FHL2 into the nucleus. At this point, the FHL2/IGFBP-5 complex may interact with other transcription modulators to stimulate transcription of target genes that may be involved in regulating osteoblast cell proliferation and differentiation [14]. Our current studies are focused towards addressing this hypothesis.

It is now known that the actions of IGFBP-5 are regulated by proteases capable of degrading IGFBP-5 into fragments. Osteoblasts in culture produce a number of proteases, including pregnancy-associated plasma protein (PAPP)-A and ADAM-9, which degrade IGFBP-5 $[20,40]$. In terms of the issue of whether the fragments generated by proteolysis of IGFBP-5 by its proteases are biologically significant, it has been shown that fragments of IGFBP-5 stimulated bone formation in vivo [35,41]. However, the relative potency of IGFBP-5 fragments generated during proteolysis of IGFBP-5 in stimulating bone formation compared with intact IGFBP-5 remains to be determined.

\section{Role of IGFBP-4 in bone}

IGFBP-4 is also a major IGFBP produced by bone cells; however, it has the opposite role of IGFBP-5. In trans-genic mice that overexpress IGFBP-4 in osteoblasts, there is a decrease in bone volume, cortical bone density, os-teoblast number, bone formation, and IGFBP-5 [42]. 
In these mice, there was a $60 \%$ decrease in bone volume compared with controls, whereas in mice overexpressing IGF-I there is a $22 \%$ increase in bone volume compared with controls [42]. Therefore, IGFBP-4 is a very important inhibitory growth factor in bone formation. Studies on the mechanism by which IGFBP-4 inhibits IGF action led to the demonstration that, upon binding to IGF, IGFBP-4 sequesters IGF and blocks it from binding to the type 1 receptor [23]. This idea was supported by an experiment demonstrating that small fragments of IGFBP-4 are less potent than intact IGFBP-4 in inhibiting IGF-induced cell proliferation $[16,43]$.

In general, in vitro experiments have consistently indicated that IGFBP-4 inhibits IGF-I- and IGF-II-induced proliferation in a number of cell types in addition to os-teoblasts [12].

Recent in vivo data have shown stimulatory and inhibitory actions of IGFBP-4 depending on the experimental conditions. For example, local administration of IGFBP-4 in mice blocked the IGF-I-induced increase in ALP activity [22]. However, when mice were treated systemically with IGFBP-4 at pharmacological doses, there was a significant increase in bone formation parameters in serum and bone extracts [22]. These unexpected results have given us a better understanding of the systemic affects of BP-4, suggesting that local and systemic administration of IGFBP-4 may have different effects on bone formation in mice. We speculate that systemically administered IGFBP-4 increased bone formation parameters due to the increase in circulating IGFBP-4 and the increase in IGF-I found in the binary complex $(50 \mathrm{kDa})$ rather than the tertiary complex $(150 \mathrm{kDa})$ [22]. The binary complex of IGF-I/IGFBP-4 is able to cross the vascular endothelium and deliver IGF-I to the cells. These data suggest that the mechanisms regulating the relative levels of binary to tertiary IGF complex could play a role in the regulation of IGF bio-availability from serum to local tissues.

A key regulator of IGF availability to local tissue is the proteolysis of IGFBP-4. We have reported direct evidence that the stimulatory action of systemically administered IGFBP-4 requires proteolysis [43]. In mice that produce low concentrations of IGF-I (midi), there was no effect of systemic IGFBP-4, and in mice injected with IGFBP-4 protease-resistant analogue, there was no increase in serum concentrations of IGF-I [43]. Therefore, we speculate that in order for IGFBP-4 to have a stimulatory effect when administered systemically, it must be cleaved from IGF-I once it passes through the vascular endothelium, allowing IGF to act on the target cell. We believe that the protease responsible for cleavage of IGFBP-4 in these experiments is the IGFBP-4 specific protease, PAPP-A. In 1999, Lawrence et al. discovered that the IGF-dependent IGFBP-4 protease produced by human fibroblasts is PAPP-A. Furthermore, we have found that PAPP-A is the major IGFBP-4 protease produced by human osteoblasts [44]. Consistent with the idea that PAPP-A is involved in regulating IGF actions via IGFBP-4 proteolysis are the findings that PAPP-A knockout mice exhibit retarded growth and delayed mineralization [45]. Overall, IGFBP-4 has an inhibitory role and is an important regulator of osteoblast development. Further experiments are needed to examine the regulation of IGFBP-4 by proteolysis and the components of the IGFBP-4 protease system involved in regulating IGF actions in bone and other tissues.

\section{Role of other IGFBPs in bone}

Unlike IGFBP-3, -4, or -5, IGFBP-6 has a greater affinity for IGF-II and is primarily inhibitory [46]. In addition, this protein is unique in that it is the only IGFBP known to potently inhibit osteoblast differentiation [46]. Previous experiments have determined that IGFBP-6 can inhibit osteoblast ALP activity and it mediates the inhibitory actions of alltrans retinoic acid (atRA) in human os-teoblasts [47]. In human osteosarcoma cells, we provided direct evidence that atRA induces an increase in IGFBP-6 that is involved in mediating the inhibitory actions of atRA on ALP activity [46]. These data led to the 
hypothesis that IGFBP-6 may act by sequestering IGF-II. However, recent studies have shown that exogenously added IGF-II did not rescue the inhibitory effect of IGFBP-6 and that extracellular IGFBP-6 was not required to inhibit osteoblast differentiation, indicating that IGF-BP-6 acts independently of IGF-II [48]. We believe that IGFBP-6 acts through an intracrine mechanism since it is able to translocate to the nucleus through a novel NLS [48]. In addition, we have determined that IGFBP-6 interacts with a protein containing the LIM mineralization protein (LMP)-1 [49], which was previously determined to induce osteoblast differentiation [50]. Based on this interaction, we hypothesize that IGFBP-6 inhibits osteoblast differentiation by sequestering LMP-1 and preventing it from stimulating osteoblast differentiation [49]. Further studies on this important IGFBP are needed to evaluate if IGFBP-6 exerts an important role in regulating osteoblast differentiation and thereby bone formation.

IGFBP-3 is the third most abundant IGFBP expressed in human osteoblasts [22]. Similar to other systems, IGFBP-3 can have inhibitory or potentiating effects in bone. Silha et al. [28] recently reported that overexpres-sion of IGFBP-3 in mice results in decreased BMD due to an inhibition of IGF-I action. Similarly, in mice overex-pressing IGFBP-3, there is an increase in osteoclast number and bone resorption, which may be a result of IGF-I inhibition because it is sequestered by the excess IGFBP-3 [28]. This decrease in BMD was associated with a decreased mitogenic response to IGF-I and decreased proliferation [28]. Since IGFBP-3 is primarily found in a tertiary complex that cannot pass through the vascular endothelium, when IGFBP-3 is in excess, it most likely binds IGF-I and prevents it from reaching target tissues. In contrast to these data, exogenously added IGFBP-3 stimulates the IGF action of osteoblasts in vitro [51]. Thus, the actions of locally produced IGFBP-3 may be different from that of IGFBP-3 in the circulation.

The other two IGFBPs expressed by osteoblasts, IGFBP-2 and IGFBP-1, primarily inhibit the actions of the IGFs. Unlike IGFBP-1, -3, and -5, IGFBP-2 must bind to IGF-II in order to bind to the extracellular matrix (ECM) [52]. Therefore, IGFBP-2 acts as a delivery molecule to increase local concentrations of IGF-II, but if ECM is not available, IGFBP-2 is a potent inhibitor of IGF action in osteoblasts [52]. The inhibitory action of IGFBP-2 in vivo has been demonstrated in transgenic mice that overexpress IGFBP-2 [53]. Excess IGFBP-2 inhibits normal and GH-stimulated bone growth, but there is no change in BMD in these mice, which indicates that IGFBP-2 may have a greater effect on bone size and mineral content than on longitudinal bone growth [53]. Limited experiments have examined the role of IGFBP-1 in bone formation; however, it is known that it may act through binding to an integrin receptor [20]. In vitro data have provided conflicting data for IGFBP-1. In human osteosarcoma cells, IGFBP-1 inhibits IGF-I-induced cell proliferation [54]; however, in chick osteoblasts, we did not observe any effect of IGFBP-1 on cell proliferation [55]. Although IGFBP-1 and -2 are not primary IGFBPs in bone formation, further work is needed to completely understand their role in bone development as well as overall growth.

\section{Summary}

The IGFs are important in bone formation since they are the most abundant growth factors found in bone and produced by osteoblasts. In addition, the six high-affinity IGFBPs that regulate the IGFs are also produced by osteoblasts. Therefore, it is important that we understand the individual roles the IGFBPs play in bone and their mechanisms of action. Many in vitro experiments have confirmed the stimulatory role of IGFBP-5 and inhibitory roles of IGFBP-4 and -6. More recent in vivo experiments have provided direct evidence that the IGFBPs not only act as carriers of the IGFs and potentiate their actions by making them available to target tissues, but some of the IGFBPs (i.e., IGFBP-5) act as IGFindependent growth factors. Although the exact mechanisms by which these IGFBPs work to potentiate or inhibit growth independently of IGF are not known, it is suggested that there 
are putative receptors or potential intracellular signaling molecules that IGFBPs can bind to. Further studies are needed to elucidate the relative contribution of the various identified signaling pathways in mediating IGF-independent effects of IGFBPs in osteoblasts. In addition, further work is needed to identify the role of the proteases and IGFBP fragments in regulating osteoblasts. In conclusion, based on the recent findings on the regulation of production and actions of IGFBPs, we would like to emphasize two main concepts: (1) IGFBPs are as important as IGF ligands in regulating osteoblasts; and (2) IGFBPs behave as independent regulators in bone and other tissues.

\section{Acknowledgments}

This work was supported by funds from the National Institutes of Health (AR31062 and AR48139) and the Department of Veterans Affairs. We would like to thank Sean Belcher for his help in the preparation of this paper.

This work was presented in part at the IPNA Seventh Symposium on Growth and Development in Children with Chronic Kidney Disease: The Molecular Basis of Skeletal Growth, 1-3 April 2004, Heidelberg, Germany

\section{References}

1. Mohan S, Richman C, Guo R, Amaar Y, Donahue LR, Wer-gedal J, Baylink DJ. Insulin-like growth factor regulates peak bone mineral density in mice by both growth hormone-dependent and independent mechanisms. Endocrinology 2003;144:929-936. [PubMed: 12586770]

2. Woods KA, Camacho-H4bner C, Savage MO, Clark A. Intrauterine growth retardation and postnatal growth failure associated with deletion of the insulin-like growth factor I gene. N Engl J Med 1996;335:1363-1367. [PubMed: 8857020]

3. Pereira Arias, A.; Walenkamp, M-J.; Hilhorst-Hofstee, Y.; Karpe-rien, M.; Van Duyvenvoorde, H.; Bax, J.; van Doorn, J.; Romijn, JA.; Wit, J-M. Clinical and biochemical expression of a homozygous missense mutation in the IGF-1 gene (abstract). Abstracts of the 85th Annual Endocrine Society Meeting; Philadelphia. 2003.

4. Walenkamp, M-J.; Pereira Arias, A.; Sluimers, C.; Hilhorst-Hofstee, Y.; van Thiel, S.; Karperien, M.; van Duyvenvoorde, H.; de Laat, J.; van Doorn, J.; Romijn, J.; Wit, J-M. Heterozygosity for a missense mutation (V44 M) in the IGF-I gene leads to a lower height and head circumference and a higher plasma IGF-I than observed in non-carriers (abstract). Abstracts of the 85th Annual Endocrine Society Meeting; Philadelphia. 2003.

5. Mohan, S.; Baylink, DJ. Role of growth hormone/insulin-like growth factor axis. In: Rosen, CJ.; Glowacki, J.; Bilezikian, J., editors. The aging skeleton. Academic Press; San Diego: 1999. p. 195-204.

6. Liu JP, Baker J, Perkins AS, Robertson EJ, Efstratiadis A. Mice carrying null mutations of the genes encoding insulin-like growth factor I (IGF-I) and type 1 IGF receptor (IGFr). Cell 1993;75:59-72. [PubMed: 8402901]

7. Baker J, Liu JP, Robertson EJ, Efstratiadis A. Role of insulin-like growth factors in embryonic and postnatal growth. Cell 1993;75:73-82. [PubMed: 8402902]

8. Yakar S, Liu J, Stannard B, Butler A, Accili D, Sauer B, LeRoith D. Normal growth and development in the absence of hepatic insulin-like growth factor I. Proc Natl Acad Sci USA 1999;96:7324-7329. [PubMed: 10377413]

9. Yakar S, Rosen CJ, Beamer WG, Ackert-Bicknell CL, Wu Y, Liu J, Ooi GT, Setser J, Frystyk J, Boisclair YR, LeRoith D. Circulating levels of IGF-I directly regulate bone growth and density. J Clin Invest 2002;110:771-781. [PubMed: 12235108]

10. Mohan S, Baylink DJ. Insulin-like growth factor system components and the coupling of bone formation to resorption. Horm Res 1996;45(Suppl 1):59-66. [PubMed: 8805034]

11. Rosen CJ, Donahue LR. Insulin-like growth factors and bone: the osteoporosis connection revisited. Proc Soc Exp Biol Med 1998;219:1-7. [PubMed: 9751217]

12. Mohan S, Baylink DJ. Serum insulin-like growth factor binding protein (IGFBP)-4 and IGFBP-5 levels in aging and age-associated diseases. Endocrine 1997;7:87-91. [PubMed: 9449039] 
13. Boonen S, Mohan S, Dequeker J, Aerssens J, Vanderschueren D, Verbeke G, Broos P, Bouillon R, Baylink DJ. Down-regulation of the serum stimulatory components of the insulin-like growth factor (IGF) system (IGF-I, IGF-II, IGF binding protein [BP]-3, and IGFBP-5) in age-related (type II) femoral neck osteoporosis. J Bone Miner Res 1999;14:2150-2158. [PubMed: 10620075]

14. Amaar YG, Thompson GR, Linkhart TA, Chen ST, Baylink DJ, Mohan S. Insulin-like growth factor binding protein-5 (IGFBP-5) interacts with a four and a half LIM protein 2 (FHL2). J Biol Chem 2002;277:12053-12060. [PubMed: 11821401]

15. Firth SM, Baxter RC. Cellular actions of the insulin-like growth factor binding proteins. Endocr Rev 2002;23:824-854. [PubMed: 12466191]

16. Qin X, Strong DD, Baylink DJ, Mohan S. Structure-function analysis of the human insulin-like growth factor binding protein-4. J Biol Chem 1998;273:23509-23516. [PubMed: 9722589]

17. Rajaram S, Baylink DJ, Mohan S. Insulin-like growth factor-binding proteins in serum and other biological fluids: regulation and functions. Endocr Rev 1997;18:801-831. [PubMed: 9408744]

18. Conover CA. Regulation and physiological role of insulin-like growth factor binding proteins. Endocr J 1996;43(Suppl):S43-S48. [PubMed: 9076341]

19. Jones JI, Clemmons DR. Insulin-like growth factors and their binding proteins: biological actions. Endocr Rev 1995;16:3-34. [PubMed: 7758431]

20. Mohan S, Baylink DJ. IGF binding proteins are multi-functional and act via IGF-dependent and IGF-independent mechanisms. J Endocrinol 2002;175:19-31. [PubMed: 12379487]

21. Rechler MM. Insulin-like growth factor binding proteins. Vitam Horm 1993;47:1-114. [PubMed: 7680510]

22. Miyakoshi N, Richman C, Qin X, Baylink DJ, Mohan S. Effects of recombinant insulin-like growth factor binding protein-4 on bone formation parameters in mice. Endocrinology 1999;140:5719-5728. [PubMed: 10579337]

23. Mohan S, Nakao Y, Honda Y, Landale E, Leser U, Dony C, Lang K, Baylink DJ. Studies on the mechanisms by which insulin-like growth factor binding protein (IGFBP-4) and IGFBP-5 modulate IGF actions in bone cells. J Biol Chem 1995;270:20424-20431. [PubMed: 7544787]

24. Jones JI, Gockerman A, Busby WH Jr, Wright G, Clemmons DR. Insulin-like growth factor binding protein 1 stimulates cell migration and binds to the alpha 5 beta 1 integrin by means of its Arg-Gly-Asp sequence. Proc Natl Acad Sci USA 1993;90:10553-10557. [PubMed: 7504269]

25. Gleeson LM, Chakraborty C, McKinnon T, Lala PK. Insulin-like growth factor-binding protein 1 stimulates human trophoblast migration by signaling through alpha 5 beta 1 in-tegrin via mitogenactivated protein kinase pathway. J Clin Endocrinol Metab 2001;86:2484-2493. [PubMed: 11397844]

26. Richman C, Baylink DJ, Lang K, Dony C, Mohan S. Recombinant human insulin-like growth factor binding protein-5 (rhIGFBP-5) stimulates bone formation parameters in vitro and in vivo. Endocrinology 1999;140:4699-4705. [PubMed: 10499528]

27. Miyakoshi N, Richman C, Kasukawa Y, Linkhart TA, Baylink DJB, Mohan S. Evidence that IGFbinding protein-5 functions as a growth factor. J Clin Invest 2001;107:73-81. [PubMed: 11134182]

28. Silha JV, Mishra S, Rosen CJ, Beamer WG, Turner RT, Powell DR, Murphy LJ. Perturbations in bone formation and resorption in insulin-like growth factor binding protein-3 transgenic mice. $\mathrm{J}$ Bone Miner Res 2003;18:1834-1841. [PubMed: 14584894]

29. Kanatani M, Sugimoto T, Mishiyama K, Chihara K. Stimulatory effect of insulin-like growth factor binding protein-5 on mouse osteoblast formation and osteoclastic bone-resorbing activity. J Bone Miner Res 2000;15:902-910. [PubMed: 10804020]

30. Jehle P, Schulten K, Jehle DR, Stracke S, Manfras B, Boehm B, Baylink DJ, Mohan S. Serum levels of insulin-like growth factor (IGF)-I and IGF binding protein (IGFBP) 1 through 6 and relationship to bone metabolism in osteoporosis patients. Eur J Intern Med 2003;14:32-38. [PubMed: 12554008]

31. Bautista CM, Baylink DJ, Mohan S. Isolation of a novel insulin-like growth factor (IGF) binding protein from human bone: a potential candidate for fixing IGF-II in human bone. Biochem Biophys Res Commun 1991;176:756-763. [PubMed: 1709017] 
32. Nicolas V, Mohan S, Honda Y, Prewett A, Finkelman RD, Baylink DJ, Farley JR. An age-related decrease in the concentration of insulin-like growth factor binding protein-5 in human cortical bone. Calcif Tissue Int 1995;57:206-212. [PubMed: 8574938]

33. Andress DL. Insulin-like growth factor-binding protein-5 (IGFBP-5) stimulates phosphorylation of the IGFBP-5 receptor. Am J Physiol 1998;274:E744-E750. [PubMed: 9575837]

34. Delvin RD, Du Z, Buccilli V, Jogetti V, Canalis E. Transgenic mice overexpressing insulin-like growth factor binding protein-5 display transiently decreased osteoblastic function and osteopenia. Endocrinology 2002;143:3955-3962. [PubMed: 12239107]

35. Andress DL. IGF-binding protein-5 stimulates osteoblast activity and bone accretion in ovariectomized mice. Am J Physiol Endocrinol Metab 2001;218:E283-E288. [PubMed: 11440904]

36. Bauss F, Lang K, Dony C, Kling L. The complex of recombinant human insulin-like growth factor-I (rhIGF-I) and its binding protein-5 (IGFBP-5) induces local bone formation in murine calvariae and in rat cortical bone after local or systemic administration. Growth Horm IGF Res 2001;11:1-9. [PubMed: 11437468]

37. Lotinun S, Sibonga JD, Turner T. Differential effects of intermittent and continuous administration of parathyroid hormone on bone histomorphometry and gene expression. Endocrine 2002;17:2936. [PubMed: 12014700]

38. Schedlich LJ, Young TF, Firth SM, Baxter RC. Insulin-like growth factor-binding protein (IGFBP)-3 and IGFBP-5 share a common nuclear transport pathway in T47D human breast carcinoma cells. J Biol Chem 1998;273:18347-18352. [PubMed: 9660801]

39. Schedlich LJ, Le Page SL, Firth SM, Briggs JL, Jans DA, Baxter RC. Nuclear import of insulinlike growth factor-binding protein-3 and; 5 is mediated by the importin beta subunit. J Biol Chem 2000;275:23462-23470. [PubMed: 10811646]

40. Mohan S, Thompson GR, Amaar YG, Hathaway G, Tschesche H, Baylink DJ. ADAM-9 is an insulin-like growth factor binding protein-5 protease produced and secreted by human osteoblasts. Biochemistry 2002;41:15394-15403. [PubMed: 12484779]

41. Andress DL, Loop SM, Zapf J, Kiefer MC. Carboxy-truncated insulin-like growth factor binding protein-5 stimulates mitogenesis in osteoblast-like cells. Biochem Biophys Res Commun 1993;195:25-30. [PubMed: 7689835]

42. Zhang M, Faugere MC, Malluche H, Rosen CJ, Chernausek SD, Clemens TL. Paracrine overexpression of IGFBP-4 in osteoblasts of transgenic mice decreases bone turnover and causes global growth retardation. J Bone Miner Res 2003;18:836-843. [PubMed: 12733722]

43. Miyakoshi N, Qin X, Richman C, Srivastava AK, Baylink DJ, Mohan S. Studies on the mechanism by which systemically administered insulin-like growth factor binding protein-4 increases bone formation parameters in mice. Endocrinology 2001;142:2641-2648. [PubMed: 11356715]

44. Qin X, Sexton C, Byun D, Strong D, Baylink D, Mohan S. Differential regulation of pregnancy associated plasma protein (PAPP)-A during pregnancy in human and mouse. Growth Horm IGF Res 2002;12:359-365. [PubMed: 12213189]

45. Conover CA, Bale LK, Overgaard MT, Johnstone EW, Laursen UH, Fuchtbauer EM, Oxvig C, Van Deursen J. Metal-loproteinase pregnancy-associated plasma protein A is a critical growth regulatory factor during fetal development. Development 2004;131:1187-1194. [PubMed: 14973274]

46. Yan T, Wergedal J, Zhou Y, Mohan S, Baylink DJ, Strong DD. Inhibition of human osteoblast marker gene expression by retinoids is mediated in part by insulin-like growth factor binding protein-6. GH and IGF Res 2001;11:368-377.

47. Zhou Y, Mohan S, Linkhart TA, Baylink DJ, Strong DD. Retinoic acid regulates insulin-like growth factor-binding protein expression in human osteoblast cells. Endocrinology 1996;137:975983. [PubMed: 8603611]

48. Strong, DD.; Chen, ST.; Linkhart, TA.; Yan, T.; Baylink, DJ.; Mohan, S. IGF binding protein-6 (BP-6) markedly inhibits os-teoblast differentiation: evidence for a intracrine mechanism involving nuclear localization utilizing a novel nuclear localization signal (NLS) (abstract). Abstracts of the 84th Annual Meeting Endocrine Society; San Francisco. 2002. 
49. Strong, DD.; Linkhart, TA.; Gunn, Y.; Kim, R.; Rung-Aroon, J.; Mohan, S.; Baylink, DJ.; Amaar, Y. Evidence that the mechanism whereby insulin-like growth factor binding protein (IGFBP)-6 markedly inhibits osteoblast differentiation is through sequestration of an activator of osteoblast differentiation, the LIM mineralization protein-1 (LMP-1) (abstract). Abstracts of the 25th Annual Meeting of American Society for Bone and Mineral Research; Minneapolis. 2003.

50. Boden SD, Liu Y, Hair GA, Helms JA, Hu D, Racine M, Nanes MS, Titus L. LMP-1, a LIMdomain protein, mediates BMP-6 effects on bone formation. Endocrinology 1998;139:5125-5134. [PubMed: 9832452]

51. Ernst M, Rodan GA. Increased activity of insulin-like growth factor (IGF) in osteoblastic cells in the presence of growth hormone $(\mathrm{GH})$ : positive correlation with the presence of the GH-induced IGF-binding protein BP-3. Endocrinology 1990;127:807-814. [PubMed: 2164921]

52. Conover CA, Khosla S. Role of extracellular matrix in insulin-like growth factor (IGF) binding protein-2 regulation of IGF-II action in normal human osteoblasts. GH and IGF Res 2003;13:328335.

53. Eckstein F, Pavicic T, Nedbal S, Schmidt C, Wehr U, Rambeck W, Wolf E, Hoeflich A. Insulinlike growth factor-binding protein-2 (IGFBP-2) overexpression negatively regulates bone size and mass, but not density, in the absence and presence of growth hormone/IGF-I excess in transgenic mice. Anat Embryol (Berl) 2002;206:139-148. [PubMed: 12478375]

54. Campbell PG, Novak JF. Insulin-like growth factor binding protein inhibits IGF action in human osteosarcoma cells. J Cell Physiol 1991;149:293-300. [PubMed: 1721071]

55. Mohan S, Bautista CM, Wergedal J, Baylink DJ. Isolation of an inhibitory insulin-like growth factor (IGF) binding protein from bone cell-conditioned medium: a potential local regulator of IGF action. Proc Natl Acad Sci USA 1989;86:8338-8342. [PubMed: 2479022] 


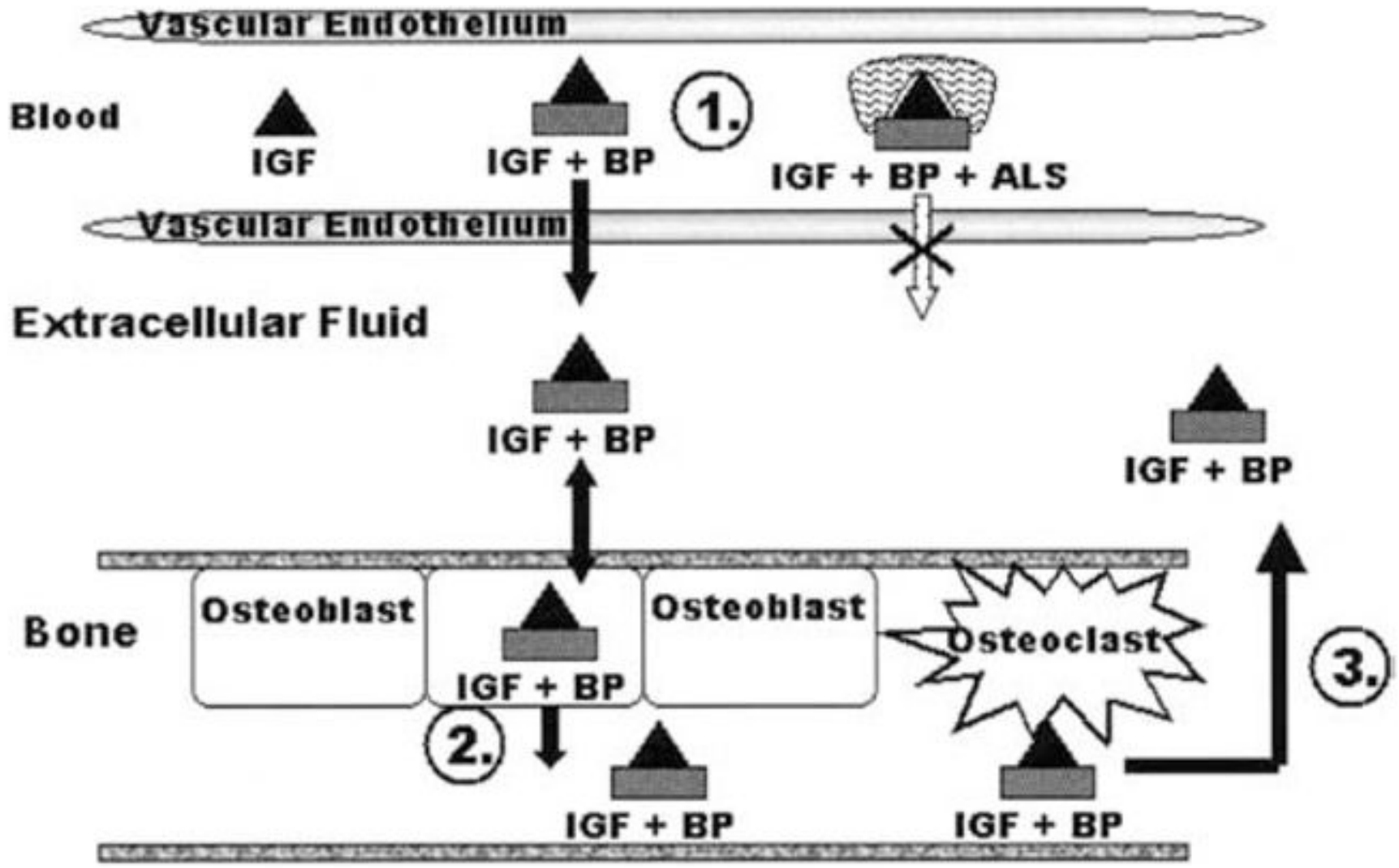

Fig. 1.

Model of systemic and local actions of insulin-like growth factor binding proteins (IGFBPs) in bone. Bone cells are exposed to IGF system components from multiple sources. (1) IGF system components from blood, which represents a systemic source; (2) locally produced IGF system components from osteoblasts, which represents a local source; and (3) IGFs and IGFBPs released from bone during osteoclastic bone resorption, which also represents a local source 


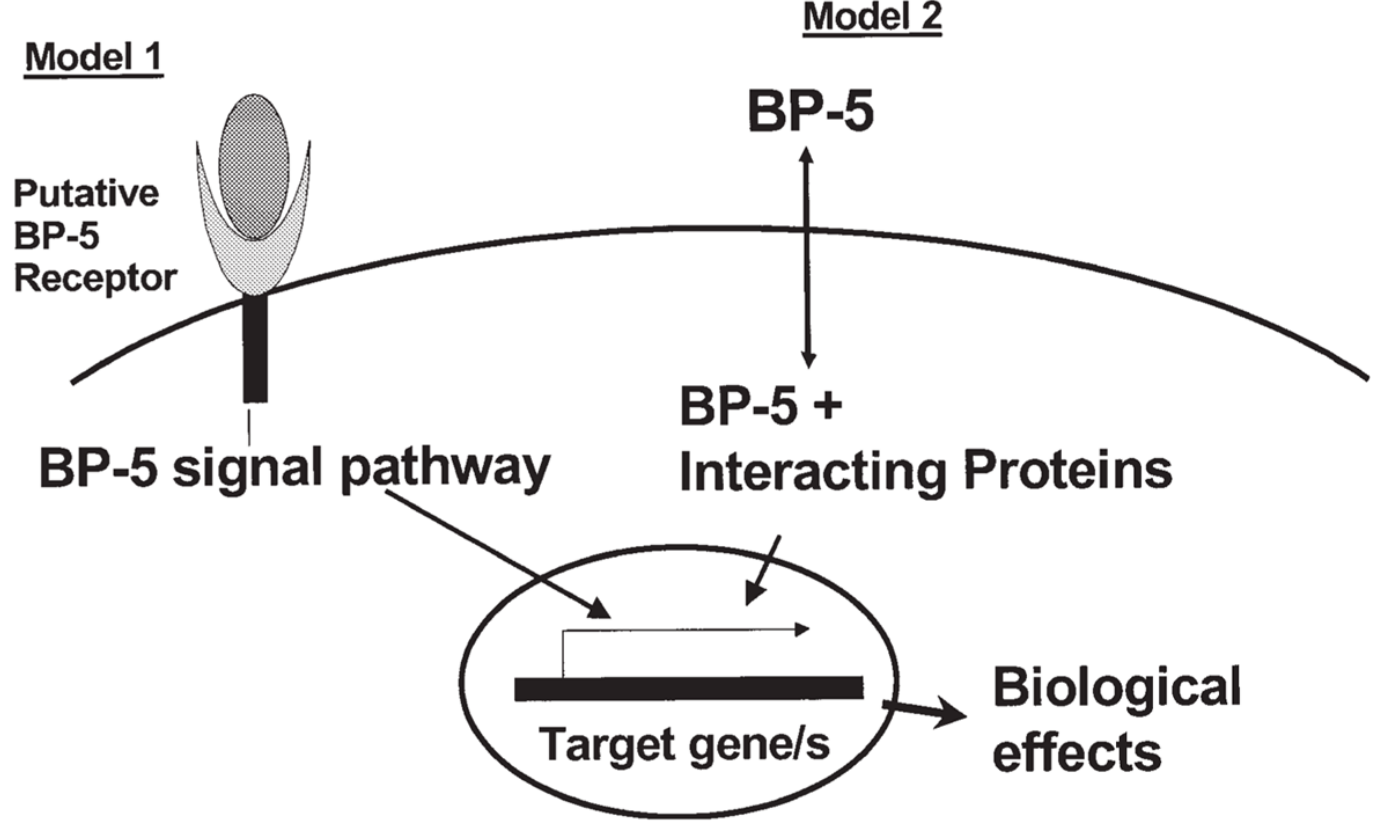

Fig. 2.

Models for IGF-independent effects of IGFBP-5. In model 1, IGFBP-5 binds to putative IGFBP-5 receptor, which has serine threonine kinase activity. Upon binding to its signaling receptor, IGFBP-5 causes activation of transcription factors, which bind to DNA to elicit biological actions. In model 2, IGFBP-5 from the cystoplasm or an extracellular source enters the nucleus via its nuclear localization sequence and transports one or more transcription factors, thereby stimulating transcription of target genes 


\section{Table 1}

Potential mechanisms by which insulin-like growth factor binding protein (IGFBP)-5 could potentiate IGF actions

\footnotetext{
1 Fix IGFs in extracellular matrix, which in turn increases concentrations of IGFs near IGF-responsive cells

2 Putative IGFBP-5 receptors on IGF-responsive cells bind IGFBP-5/IGF complex and increase concentrations of IGFs near the type 1 receptor

3 Increase half-life of IGFs by protecting them from proteolysis

4 Prevent escape of IGFs produced by osteoblasts into circulation and thereby increase concentrations of IGFs in bone microenvironment

$5 \quad$ Interaction between IGFBP-5 signaling pathway and IGF signaling pathway
} 